\title{
Formulation and Evaluation of Transdermal Patch of Diclofenac Sodium
}

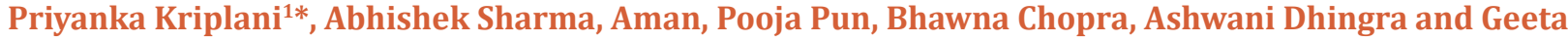 \\ Deswal $^{1}$ \\ ${ }^{1}$ Department of Pharmaceutics, Guru Gobind Singh College of Pharmacy, India
}

Submission: October 05, 2017; Published: February 19, 2018

*Corresponding author: Priyanka Kriplani, Department of Pharmaceutics, Guru Gobind Singh College of Pharmacy, India, Tel: 7206120128;

Email: priyanka15n@gmail.com

\begin{abstract}
Transdermal drug delivery has made an important contribution to medical practice. It is a medicated patch that delivers a specific amount of medication through the skin into the blood stream. An advantage of a transdermal drug delivery route over other types of medication delivery is that the patch provides a controlled release of the medication into the patient, usually through either a porous membrane covering a reservoir of medication or through body heat melting thin layers of medication embedded in the adhesive. The present investigation was aimed to formulate transdermal films of non steroidal anti-inflammatory drug, Diclofenac sodium using mercury substrate method and evaluated for physicochemical parameters like thickness, weight variation, moisture uptake, moisture content, folding endurance, and drug content values. Three transdermal patches were prepared using different concentrations of ethyl cellulose. It was concluded that as the concentration of polymer increases the thickness of patch, weight uniformity and folding endurance increases. Percentage moisture content and percentage moisture uptake decreases with increase in polymer concentration.
\end{abstract}

Keywords : Transdermal; Inflammation; Skin; NSAID; Polyethylene glycol

\section{Introduction}

Transdermal patch generally refers to topical application delivers agents to healthy intact skin either for localized treatment of tissues underlying the skin or for systemic therapy. Transdermal Patch offers many advantages over the conventional dosage forms or controlled release oral systems. Transdermal patch provides constant blood levels, avoids first pass metabolism, increased patient compliance, and avoids dose dumping [1,2]. The application of transdermal delivery to a wider range of drugs is limited due to the significant barrier to penetration across the skin which is allied primarily with the outermost stratum corneum layer of the epidermis. Formulation on skin can be classified into two categories according to the target site of the action. One has systemic action after drug uptake from the cutaneous micro vascular network and other exhibits local effects in the skin. Transdermal drug delivery can closely mimics the slow intravenous infusion without its potential hazards and also offer another most important advantage in allowing the patient to terminate the drug therapy by simply removing the patch at desired time if toxicity develops [3].

NSAID (Non-steroidal anti-inflammatory drugs) are mostly used for the preparation of transdermal patches for the treatment of inflammation or pain. The NSAID patches are safer and convenient than its oral form. Patient with rheumatism received different NSAID tablets. The side effects like stomach bleeding, increased acidity, ulcers are avoided by using transdermal patches of NSAID. The analgesic patch of NSAID may be used on the site of bruise, sprain or strain. These patch when applied topically in the form of transdermal patch, without reaching higher plasma drug concentrations the drug penetrate the skin, subcutaneous fatty tissue, and muscle in amounts sufficient to exert local therapeutic effects. Hence NSAIDs offer the advantage of local, enhanced drug delivery to affected tissues with a reduced incidence of systemic adverse events. In Rheumatoid Arthritis patients are advised to take the NSAIDs for prolong period but the side effects related to systemic toxicity and GIT irritation are the main drawbacks of NSAIDs drugs [4,5].

Diclofenac sodium is non steroidal anti-inflammatory agent, widely used in musculoskeletal disorders, arthritis, toothache, etc., for symptomatic relief of pain and inflammation. Diclofenac sodium is reportedly used for topical applications. The drug undergoes substantial hepatic first-pass metabolism and only about $50 \%$ of administered dose reaches systemic circulation. In Rheumatoid Arthritis patients are advised to take the NSAIDs 
for prolong period but the side effects such as systemic toxicity, GIT irritation, nausea, vomiting, gastric erosion, headache are the main drawbacks of Diclofenac sodium. Because of its short biological half-life and frequent administration, it is considered as a suitable candidate to formulate it into a sustained release matrix type transdermal patch system. Main objective of study is to develop transdermal patch of Diclofenac sodium to achieve more patient compliance, to reduce the dosing frequency, to enhance the release rate of drug for quick onset of action, to avoid the oral administration of drug to omit the GIT related bioavailability problems and to improve local availability of drug to site of action in arthritis [6].

\section{Materials and Methods}

\section{Materials}

All the chemicals used in this research were of standard pharmaceutical grade. Diclofenac sodium was procured as a gift sample from Cipla Pharmaceuticals, Mohali. Ethyl Cellulose (Titan biotech Ltd., Bhiwadi, Rajasthan), PEG-400 (SD Fine chemicals, Mumbai), Dibutylphthalate (Nice Chemicals, Cochin), Methanol (Nice Chemicals, Cochin) and chloroform (SD Fine chemicals, Mumbai) were of analytical reagent grade.

\section{Methods}

Ethyl Cellulose was used for the formulation of Transdermal Patch. Polyethylene glycol (PEG 400) was used as a plasticizer. Dibutylphthalate is used as penetration enhancer. The polymer was dissolved in chloroform: methanol (1:1) solvent. The drug was dispersed uniformly in the viscous solution with continuous stirring. The resulting mass was poured into leveled mercury surface in a Petri dish covered with inverted funnel. The Petri dish was left undisturbed at room temperature for one day. The patch was obtained intact by slowly lifting from the Petri dish and transdermal patches were cut into radius of $2 \mathrm{~cm} 2$ [7-9] (Table 1).

Table 1: Formulation Design.

\begin{tabular}{|c|c|c|c|}
\hline Ingredients & F1 & F2 & F3 \\
\hline Diclofenac sodium (mg) & 10 & 10 & 10 \\
\hline Ethyl Cellulose (mg) & 200 & 300 & 400 \\
\hline PEG-400 (ml) & 1.2 & 1.2 & 1.2 \\
\hline Dibutyl phthalate (ml) & 1.2 & 1.2 & 1.2 \\
\hline Chloroform: Methanol & $1: 4$ & $1: 4$ & $1: 4$ \\
\hline
\end{tabular}

\section{Evaluation and Characterization}

\section{Thickness of patch}

The thickness of each patch was measured by using screw gauge at five different positions of the patch and the average was calculated [10].

\section{Weight uniformity}

Patches sizes of $2 \mathrm{~cm}$ radius ( $4 \mathrm{~cm}$ diameter) was cut. The weights of five patches were taken and the weight variation was calculated [11].

\section{Folding endurance}

A patch of $2 \mathrm{~cm}$ radius ( $4 \mathrm{~cm}$ diameter) was cut evenly and repeatedly folded at the same place till it brakes. The numbers of times the film was folded at the same place without breaking give the value of the folding endurance $[12,13]$.

\section{Percentage moisture content}

The prepared films were weighed individually and kept in a desiccators containing fuse calcium chloride at room temperature for $24 \mathrm{~h}$. After $24 \mathrm{~h}$, the films were reweighed and determined the percentage moisture content from the mentioned formula $[14,15]$.

\section{Percentage moisture uptake}

The weighed films were kept in desiccators at room temperature for $24 \mathrm{~h}$ containing saturated solution of potassium chloride in order to maintain $84 \%$ RH. After $24 \mathrm{~h}$, the films were reweighed and determined the percentage moisture uptake from the below mentioned formula $[16,17]$.

\section{Drug content}

A specified area of patch was dissolved in a phosphate buffer solution. The content was stirred to dissolve the film. The content was transferred to a volumetric flask. The absorbance of the solution was measured at wavelength $284 \mathrm{~nm}$ and determines the drug content [18].

\section{Results and Discussion}

The spectrum of UV was analyzed by UV/Vis spectroscopy and $\lambda_{\max }$ found to be $267 \mathrm{~nm}$ at $\mathrm{pH} 5.8$ with $\mathrm{R}^{2}$ value of 0.9856 . (Table 2-4) (Figure 1). It can be concluded that as the concentration of polymer increases the thickness of patch, weight uniformity, folding endurance increases. Percentage moisture content and percentage moisture uptake and drug release decreases with increase in polymer concentration.

Table 2 : Preparation of Standard Curve of Diclofenac sodium at $\mathrm{pH}$ 5.8 .

\begin{tabular}{|c|c|}
\hline Concentration $\mathbf{~ m c g} / \mathbf{m l}$ & Absorbance \\
\hline 2 & 0.001 \\
\hline 4 & 0.039 \\
\hline 6 & 0.099 \\
\hline 8 & 0.178 \\
\hline 10 & 0.247 \\
\hline
\end{tabular}

Table 3 : Evaluation of Diclofenac sodium Transdermal Patch.

\begin{tabular}{|c|c|c|c|}
\hline $\begin{array}{c}\text { Formulation } \\
\text { Code }\end{array}$ & $\begin{array}{c}\text { Thickness } \\
\text { (mm) }\end{array}$ & $\begin{array}{c}\text { Weight } \\
\text { Uniformity } \\
\text { (gm) }\end{array}$ & $\begin{array}{c}\text { Folding } \\
\text { Endurance }\end{array}$ \\
\hline F1 & $0.512 \pm 0.03$ & $0.298 \pm 0.02$ & $120.0 \pm 2.6$ \\
\hline F2 & $0.514 \pm 0.06$ & $0.352 \pm 0.04$ & $112.0 \pm 2.7$ \\
\hline F3 & $0.518 \pm 0.06$ & $0.402 \pm 0.02$ & $99.0 \pm 2.6$ \\
\hline
\end{tabular}




\section{Global Journal of Pharmacy \& Pharmaceutical Sciences}

Table 4 : Evaluation of Diclofenac sodium Transdermal Patch.

\begin{tabular}{|c|c|c|c|}
\hline $\begin{array}{c}\text { Formulation } \\
\text { Code }\end{array}$ & $\begin{array}{c}\text { \%Moisture } \\
\text { Content }\end{array}$ & $\begin{array}{c}\text { \%Moisture } \\
\text { Uptake }\end{array}$ & $\begin{array}{c}\text { Drug Content } \\
\text { (mg) }\end{array}$ \\
\hline F1 & $6.16 \pm 0.12$ & $5.85 \pm 0.22$ & $80.64 \pm 0.25$ \\
\hline F2 & $5.25 \pm 0.23$ & $4.83 \pm 0.26$ & $74.18 \pm 0.32$ \\
\hline F3 & $4.22 \pm 0.66$ & $4.65 \pm 0.45$ & $68.43 \pm 0.50$ \\
\hline
\end{tabular}

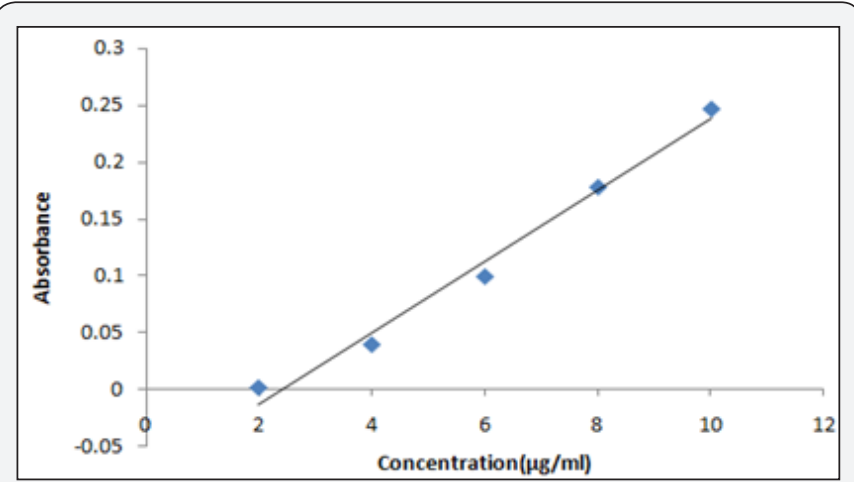

Figure 1: Standard curve of Diclofenac sodium.

\section{Conclusion}

The transdermal patch of Diclofenac sodium was prepared successfully by using different concentrations of ethyl cellulose by solvent casting method. The present work can further be proceeding with in-vivo study on healthy animals to evaluate the pharmacokinetic profile.

\section{References}

1. Goyal A, Kumar S, Nagpal M, Singh I, Arora S (2011) Potential of Novel Drug Delivery Systems for Herbal Drugs. Indian Journal of pharmaceutical Research and Education 45(3): 225-235.

2. Archer HK, Pettit MS (1997) Analgesic and antiphlogistic compositions and therapeutic wrap for topical delivery.

3. Ghulaxe C, Verma R (2015) A review on transdermal drug delivery system. The Pharma Innovation Journal 4(1): 37-43.

4. Rathore B, Mahidi AA, Paul BN, Saxena PN, Das SK (2007) Indian herbal medicines: possible potent therapeutic agents for rheumatoid arthritis. Journal of Clinical Biochemistry and Nutrition. 41(1): 12-17.

5. Park YG, Ha CW, Han D, Bin S, Kim HC, et al. (2013) A prospective, randomized, double-blind, multicenter comparative study on the safety and efficacy of Celecoxib and GCSB-5,dried extracts of six herbs, for the treatment of of osteoarthritis of knee joint. J Ethnopharmacol 149(3): 816-824.

6. Sahoo BJ, Mishra AN (2013) Formulation and evaluation of transdermal patches of diclofenac. World Journal of Pharmacy and Pharmaceutical Sciences 2(6): 4965-4971.

7. Gowda DV, Rajesh N, Somashekhara CN, Siddaramaiah (2010) Development and evaluation of Aceclofenac loaded transdermal film. International Journal of Pharmtech Research 2(4): 2224-2233.

8. Patel RP, Patel G, Baria A (2009) Formulation and evaluation of transdermal patch of Aceclofenac. International Journal of Drug Delivery 1: 41-51.

9. Gaikwad AK (2013) Transdermal drug delivery system: formulation aspects and evaluation. J Pharm Sci 1(1): 1-10.

10. Santosh G, Dhaval P, Mantesh K, Ajay S, Vital V (2009) Formulation and evaluation of matrix type transdermal patches of Glibenclamide. Int J of Pharmaceutical Sciences and Drug Research 1(1): 46-50.

11. Kumar SS, Behury B, Sachinkumar P (2013) Formulation and evaluation of transdermal patch of Stavudine. J Pharm Sci 12(1): 63-69.

12. Prabhakar P, Shah S, Gundad (2011) Formulation development and investigation of Domperidone transdermal patches. Int J of Pharm Investig 1(4): 240-246.

13. Jadhav RT, Kasture PV, Gattani SG, Surana SJ (2009) Formulation and evaluation of transdermal films of diclofenac sodium. Int.J. Pharmtech Res 1(4): 1507-1511.

14. Murthy SN, Rani S, Hiremath R (2001) Formulation and evaluation of controlled release transdermal patches of theophylline-salbutamol sulphate. Indian Journal of Pharmaceutical Education and Research 27(2): 1057-1062.

15. Saxena M, Mutalik S, Reddy MS (2006) Formulation and evaluation of transdermal patches of metoclopramide hydrochloride. Indian drugs 43(9): 740-745.

16. Mali AD, Bathe R, Patil M (2015) An updated review on transdermal drug delivery systems. International Journal of Advances in Scientific Research 1(06): 244-254.

17. Darwhekar G, Jain DK, Patidar PK (2011) Formulation and evaluation of transdermal drug delivery system of Clopidogrel bisulfate. Asian Journal of Pharmacy and Life Science 1(3): 26.

18. Prajapati ST, Patel CG, Patel CN (2011) Formulation and Evaluation of transdermal Patch of repaglinide. ISRN Pharma 2: 65-78. 

(C) 1 Th
Commons Attribution 4.0 License
DOI: $10.19080 / G J P P S .2018 .04 .555647$
Your next submission with Juniper Publishers will reach you the below assets

- Quality Editorial service

- Swift Peer Review

- Reprints availability

- E-prints Service

- Manuscript Podcast for convenient understanding

- Global attainment for your research

- Manuscript accessibility in different formats

( Pdf, E-pub, Full Text, Audio)

- Unceasing customer service

Track the below URL for one-step submission https://juniperpublishers.com/online-submission.php 